\title{
Association of Extracranial Carotid Artery Stenosis in Ischemic Stroke in a Sri Lankan Cohort of Patients - An Analytical Cross-Sectional Study
}

\author{
Ishani Rajapakshe ${ }^{* 1}$ (MBBS, MD, MRCP), Devasmitha Wijesundara ${ }^{1}$ (MBBS), \\ Amila Chandrakumara ${ }^{2}$ (MBBS, MD), Bimsara Senanayake ${ }^{1}$ (MBBS, MD, FRCP, FCCP) \\ ${ }^{1}$ Institute of Neurology, National Hospital of Sri Lanka \\ ${ }^{2}$ Department of Neuroradiology, National Hospital of Sri Lanka \\ *Corresponding author: Ishani Rajapakshe; Orcid id: https://orcid.org/0000-0003-1465-2870; \\ shanira17th@yahoo.com;
}

Received 16 February 2022;

Accepted 28 February 2022;

Published 03 March 2022

\begin{abstract}
Background and Objectives: The burden of stroke in Sri Lanka is on the increase with the current demographic transition toward an ageing population. However, the association of symptomatic extracranial carotid artery stenosis (CAS) in ischemic stroke has not been prospectively evaluated in a Sri Lankan cohort of ischemic stroke patients. Globally population-based studies have estimated about $15 \%$ of ischemic strokes are caused by large vessel occlusions. It is commonly believed that the prevalence of significant extracranial CAS is low in Sri Lanka compared to western populations. The purpose our study is to systematically analyses and assess this long held notion and to search for other associated causative factors. Methods: The study population comprised of 164 acute ischemic stroke patients admitted consecutively to the National hospital of Sri Lanka over a period of 3 months. Carotid artery duplex scans were done by a single well-trained operator within 2 weeks of presentation and degree of CAS was classified as low ( $<50 \%)$, moderate (50-69\%), severe $(>70 \%)$ and complete occlusion according to NASCET criteria. Factors associated with CAS were identified by stepwise multiple logistic regression analysis. Results: Out of 164 ischemic stroke patients $104(63.4 \%)$ were male and $60(36.6 \%)$ were female. The mean age of stroke patients was $62.2+-14.21$ years. $139(84.8 \%)$ had low grade stenosis, $10(6.1 \%)$ had moderate stenosis, $7(4.2 \%)$ had severe stenosis and $8(4.9 \%)$ had complete stenosis of carotid artery. Older age and presence of previous TIAs were significantly associated with CAS. Gender, hypertension, diabetes mellitus, hypercholesterolemia, IHD, previous stroke, previous TIA, previous use of antiplatelets, family history of stroke, previous use of statins and presence of carotid bruit were not significantly associated. Conclusion: Extracranial carotid artery occlusion previously considered a rare cause of ischemic stroke in Sri Lanka was found to be having prevalence similar to western populations in this study with over $15 \%$ having significant stenosis. Hence, we emphasize that early carotid doppler studies must be performed in all ischemic strokes at least within two weeks and necessary interventions carried out where it is deemed necessary.
\end{abstract}

Keywords: Extracranial Carotid artery stenosis, Sri Lanka, NASCET criteria, Ischemic stroke, Endarterectomy, Risk factors

\section{Introduction}

Stroke is one of the principal causes of disability and death worldwide. About 15 million suffer from stroke each year according to World Health Organization and 5 million out of them dies and another 5 million are permanently disabled ${ }^{[1]}$. The prevalence of stroke is 10.4 per 1000 population in urban Sri Lanka, but only limited data is available on true prevalence in whole population including rural population ${ }^{[2]}$. All thrombotic strokes can be due to small or large vessel disease. Large vessel thrombosis includes both intracranial and extracranial stenosis which causes approximately 15\% ischemic stroke according large population-based studies ${ }^{[4,5,6]}$. It is one of the commonest causes of early recurrent strokes ${ }^{[3]}$. Atherothrombosis is thought to be commonest cause for carotid artery occlusive disease.

The prevalence of extracranial CAS in Sri Lanka is not systematically evaluated to date in a prospective fashion. Timely diagnosis and correct intervention will help to prevent further episodes of ischemic events which can lead to permanent disability or even death. An early diagnosis of CAS is of paramount importance following TIA and ischemic stroke. The delay is usually due to unavailability of imaging facilities such as carotid duplex and CT angiogram (CTA) in some suburban and rural centers, huge patient loads leading to overcrowding and dearth of 
dedicated trained neuro-radiologists. Even with an early diagnosis managing CAS with carotid endarterectomy (CAE) or carotid artery stenting is a challenging task in a resource poor setting. Currently in Sri Lanka evidence for a strong association between extracranial CAS and stroke is lacking. The findings in this study would be beneficial in taking management decisions such as CEA in the future.

\section{Methods}

The study population comprised of patients with acute ischemic stroke fulfilling inclusion criteria for the study and admitted to National hospital of Sri Lanka over a period of 3 months. They were randomly assigned to the study and patients with hemorrhagic strokes, head injury, underlying congenital or acquired thrombophilia causing ischemic strokes were excluded. Carotid artery duplex scan of all eligible patients was performed by a single well trained senior registrar in neuroradiology within 2 weeks of the diagnosis of ischemic stroke. The scan findings were documented for individual patients. Degree of CAS was classified as low $(<50 \%)$, moderate $(50-69 \%)$, severe $(>70 \%)$ and complete occlusion according to NASCET criteria. Important data for evaluation was collected by a trained medical officer in neurology at the same time via an interviewer administered questionnaire combined with a section on patient details obtained through medical records of the patient. The questionnaire consisted of demographic data, modifiable and non-modifiable risk factors such as diabetes mellitus, hypertension, hypercholesterolemia, ischemic heart disease, smoking, and alcohol, a positive family history, previous history of TIA and stroke, drug history including previous statin and antiplatelet use and details related to current admission and disability assessment. Data was entered with appropriate data checks and cleaning. They were analyzed using the SPSS. Findings were described as frequency percentages and factors associated with CAS were identified by stepwise multiple logistic regression analysis.

\section{Results}

A cohort of 164 patients with first or recurrent ischemic strokes were evaluated. Demographic characteristics, modifiable and nonmodifiable risk factors of the study population are presented in Table 1. Mean age of the population was $62.2+-14.2$ years. $14.6 \%$ were less than 45 years of age, $15.9 \%$ was above 76 years of age and majority of the study population belonged to 66-75 age category. Majority of the patients studied $63.4 \%$ (104/164) were males. Tobacco and alcohol usage amongst them was $39.6 \%$ and $43.9 \%$ respectively. Hypertension being the commonest non modifiable risk factor was present in $50.6 \%$ of those evaluated. Hypercholesterolemia, diabetes mellitus and ischemic heart disease was seen in $45.1 \%, 39.6 \%$ and $22 \%$ respectively.

Table 1: Frequency of demographic, risk factors and previous drug (antiplatelet and statin) exposure

\begin{tabular}{|c|c|c|c|}
\hline & & Number of patients & Percentage $(\%)$ \\
\hline \multicolumn{4}{|l|}{ Demographics } \\
\hline Age & $\begin{array}{l}<45 \\
46-55 \\
55-65 \\
66-75 \\
>76\end{array}$ & $\begin{array}{l}24 \\
24 \\
37 \\
53 \\
26\end{array}$ & $\begin{array}{l}14.6 \\
14.6 \\
22.6 \\
32.3 \\
15.9\end{array}$ \\
\hline Gender & Male Female & $\begin{array}{l}104 \\
60\end{array}$ & $\begin{array}{l}63.4 \\
36.6\end{array}$ \\
\hline BMI (Body Mass Index) & $\begin{array}{l}<18 \\
19-23 \\
24-30 \\
>31\end{array}$ & $\begin{array}{l}13 \\
65 \\
65 \\
21\end{array}$ & $\begin{array}{l}7.9 \\
39.6 \\
39.6 \\
12.8\end{array}$ \\
\hline \multicolumn{4}{|l|}{ Risk Factors } \\
\hline Tobacco used & $\begin{array}{l}\text { No } \\
\text { Yes }\end{array}$ & $\begin{array}{l}99 \\
65\end{array}$ & $\begin{array}{l}60.4 \\
39.6\end{array}$ \\
\hline Alcohol used & $\begin{array}{l}\text { No } \\
\text { Yes }\end{array}$ & $\begin{array}{l}92 \\
72\end{array}$ & $\begin{array}{l}56.1 \\
43.9\end{array}$ \\
\hline Hypertension & No Yes & $\begin{array}{l}81 \\
83\end{array}$ & $\begin{array}{l}49.4 \\
50.6\end{array}$ \\
\hline Hypercholesteremia & $\begin{array}{l}\text { No } \\
\text { Yes }\end{array}$ & $\begin{array}{l}90 \\
74\end{array}$ & $\begin{array}{l}54.9 \\
45.1\end{array}$ \\
\hline Diabetes mellitus & $\begin{array}{l}\text { No } \\
\text { Yes }\end{array}$ & $\begin{array}{l}99 \\
65\end{array}$ & $\begin{array}{l}60.4 \\
39.6\end{array}$ \\
\hline Atrial fibrillation & $\begin{array}{l}\text { No } \\
\text { Yes }\end{array}$ & $\begin{array}{l}150 \\
14\end{array}$ & $\begin{array}{l}91.5 \\
8.5\end{array}$ \\
\hline Ischemic heart disease & $\begin{array}{l}\text { No } \\
\text { Yes }\end{array}$ & $\begin{array}{l}128 \\
36\end{array}$ & $\begin{array}{l}78 \\
22\end{array}$ \\
\hline Previous TIA (Transient Ischemic attack) & $\begin{array}{l}\text { No } \\
\text { Yes }\end{array}$ & $\begin{array}{l}137 \\
27\end{array}$ & $\begin{array}{l}83.5 \\
16.5\end{array}$ \\
\hline Previous Stroke & $\begin{array}{l}\text { No } \\
\text { Yes }\end{array}$ & $\begin{array}{l}128 \\
36\end{array}$ & $\begin{array}{l}78 \\
22\end{array}$ \\
\hline Family history of stroke & $\begin{array}{l}\text { No } \\
\text { Yes }\end{array}$ & $\begin{array}{l}133 \\
31\end{array}$ & $\begin{array}{l}81.1 \\
18.9\end{array}$ \\
\hline
\end{tabular}




\begin{tabular}{|l|l|l|l|}
\hline Previous antiplatelet used & No & 128 & 78 \\
& Yes & 36 & 22 \\
\hline Previous statin used & No & 99 & 60.4 \\
& Yes & 65 & 39.6 \\
\hline
\end{tabular}

$25(15.2 \%)$ of ischemic strokes were attributed to extracranial CAS stenosis, out of which $8(4.9 \%)$ patients had complete stenosis where no intervention was indicated. 7(4.2\%) and 10(6.1\%) had $70-99 \%$ and $50-69 \%$ ipsilateral extracranial CAS respectively. Carotid endarterectomy is indicated for these patients if the stroke is non - disabling, in selected cases within 2 weeks. All patients should undergo imaging either with CTA or MRA prior to surgery. All patients (17) who were eligible for carotid endarterectomy underwent either CTA or MRA. Amongst 17 patients who were evaluated for endarterectomy, 5(29.4\%) patients had tandem lesions and these patients were not eligible for endarterectomy as they demonstrated both intracranial and extracranial CAS. Among 25 patients with ipsilateral CAS $12 \%$ (3) had lacunar strokes and all other had MCA/ACA stroke. Among 25 patients with large vessel mechanisms, none had a potential cardiac source of embolus or atrial fibrillation.

Degree of extracranial stenosis are presented in table 2 and graph 1.

Table 2: Degree of extracranial carotid artery stenosis

\begin{tabular}{|l|l|l|}
\hline Degree of Stenosis & Number of Cases & Percentage (\%) \\
\hline Complete Stenosis (100\%) & 8 & 4.9 \\
\hline Severe Stenosis (70-99\%) & 7 & 4.2 \\
\hline Moderate Stenosis (50-69\%) & 10 & 6.1 \\
\hline Low Grade Stenosis (<50\%) & 139 & 84.8 \\
\hline
\end{tabular}

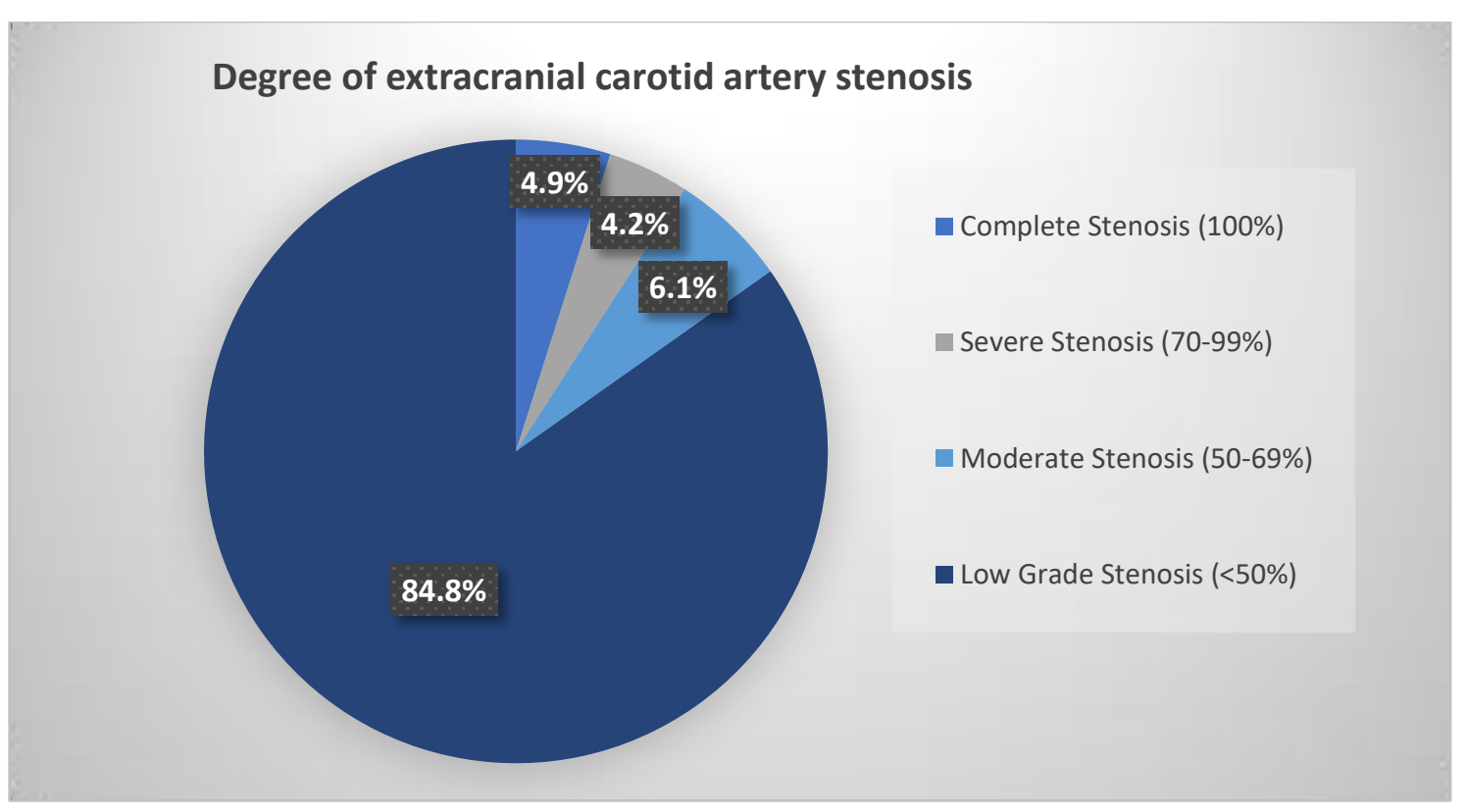

Graph 1: Degree of extracranial carotid artery stenosis

Association of demographic characteristics, risk factors and previous drug exposure are elaborated in table 3. There is significant association of older age $(\mathrm{p}$ value $=0.272)$ and previous TIA $(\mathrm{p}$ value $=0.140)$ with extracranial CAS where as other factors are not significantly associated.

Table 3: Association of extracranial carotid artery stenosis (CAS) with demographics, risk factors and previous drug history

\begin{tabular}{|c|c|c|c|c|c|}
\hline & \multicolumn{4}{|c|}{ Degree of extracranial CAS } & \multirow[t]{2}{*}{$P$ value } \\
\hline & $\begin{array}{l}\text { Complete stenosis } \\
(\mathbf{1 0 0 \% )}-\mathbf{0 8}\end{array}$ & $\begin{array}{l}\text { Severe stenosis } \\
(\mathbf{7 0 - 9 9 \% )}-07\end{array}$ & $\begin{array}{l}\text { Moderate stenosis } \\
(50-69 \%)-10\end{array}$ & $\begin{array}{l}\text { Low grade stenosis } \\
(<50 \%)-139\end{array}$ & \\
\hline $\begin{array}{l}\text { Gender } \\
\text { Male } \\
\text { Female }\end{array}$ & $\begin{array}{l}6(75 \%) \\
2(25 \%)\end{array}$ & $\begin{array}{l}4(57.1 \%) \\
3(42.9 \%)\end{array}$ & $\begin{array}{l}3(30 \%) \\
7(70 \%)\end{array}$ & $\begin{array}{l}91(65.5 \%) \\
48(34.5 \%)\end{array}$ & $<0.05$ \\
\hline $\begin{array}{l}\text { Age (years) } \\
\text { Less than } 45 \\
46-55 \\
56-65 \\
66-75 \\
\text { More than } 76\end{array}$ & $\begin{array}{l}1(12.5 \%) \\
1(12.5 \%) \\
1(12.5 \%) \\
1(12.5 \%) \\
4(50 \%)\end{array}$ & $\begin{array}{l}1(14.3 \%) \\
3(42.8 \%) \\
2(28.6 \%) \\
1(14.3 \%) \\
0(0)\end{array}$ & $\begin{array}{l}1(10 \%) \\
2(20 \%) \\
3(30 \%) \\
4(40 \%) \\
0(0)\end{array}$ & $\begin{array}{l}21(15.1 \%) \\
18(12.9 \%) \\
31(22.3 \%) \\
47(33.8 \%) \\
22(15.9 \%)\end{array}$ & 0.272 \\
\hline $\begin{array}{l}\text { Body Mass Index } \\
\text { Less than } 18 \\
19-23\end{array}$ & $\begin{array}{l}0(0) \\
5(62.5 \%)\end{array}$ & $\begin{array}{l}0(0) \\
5(71.4 \%)\end{array}$ & $\begin{array}{l}1(10 \%) \\
4(40 \%)\end{array}$ & $\begin{array}{l}12(8.6 \%) \\
51(36.7 \%)\end{array}$ & $<0.05$ \\
\hline
\end{tabular}




\begin{tabular}{|c|c|c|c|c|c|}
\hline $\begin{array}{l}24-30 \\
\text { More than } 31\end{array}$ & $\begin{array}{l}3(37.5 \%) \\
0(0)\end{array}$ & $\begin{array}{l}2(28.6 \%) \\
0(0)\end{array}$ & $\begin{array}{l}5(50 \%) \\
0(0)\end{array}$ & $\begin{array}{l}55(39.6 \%) \\
2115.1 \%)\end{array}$ & \\
\hline $\begin{array}{l}\text { Tobacco use } \\
\text { No } \\
\text { Yes }\end{array}$ & $\begin{array}{l}6(75 \%) \\
2(25 \%)\end{array}$ & $\begin{array}{l}5(71.4 \%) \\
2(28.6 \%)\end{array}$ & $\begin{array}{l}3(30 \%) \\
7(70 \%)\end{array}$ & $\begin{array}{l}85(61.2 \%) \\
54(38.8 \%)\end{array}$ & $<0.05$ \\
\hline $\begin{array}{l}\text { Alcohol use } \\
\text { No } \\
\text { Yes }\end{array}$ & $\begin{array}{l}6(75 \%) \\
2(25 \%)\end{array}$ & $\begin{array}{l}5(71.4 \%) \\
2(28.6 \%)\end{array}$ & $\begin{array}{l}4(40 \%) \\
6(60 \%)\end{array}$ & $\begin{array}{l}84(60.4 \%) \\
55(39.6 \%)\end{array}$ & $<0.05$ \\
\hline $\begin{array}{l}\text { Diabetes mellitus } \\
\text { No } \\
\text { Yes }\end{array}$ & $\begin{array}{l}6(75 \%) \\
2(25 \%)\end{array}$ & $\begin{array}{l}4(57.1 \%) \\
3(42.9 \%)\end{array}$ & $\begin{array}{l}9(90 \%) \\
1(10 \%)\end{array}$ & $\begin{array}{l}80(57.6 \%) \\
59(42.4 \%)\end{array}$ & $<0.05$ \\
\hline $\begin{array}{l}\text { Hypertension } \\
\text { No } \\
\text { Yes }\end{array}$ & $\begin{array}{l}3(37.5 \%) \\
5(62.5 \%)\end{array}$ & $\begin{array}{l}2(28.6 \%) \\
5(71.4 \%)\end{array}$ & $\begin{array}{l}8(80 \%) \\
2(20 \%)\end{array}$ & $\begin{array}{l}68(48.9 \%) \\
71(51.1 \%)\end{array}$ & $<0.05$ \\
\hline $\begin{array}{l}\text { Hypercholesterolemia } \\
\text { No } \\
\text { Yes }\end{array}$ & $\begin{array}{l}3(37.5 \%) \\
5(62.5 \%)\end{array}$ & $\begin{array}{l}4(57.1 \%) \\
3(42.9 \%)\end{array}$ & $\begin{array}{l}8(80 \%) \\
2(20 \%)\end{array}$ & $\begin{array}{l}75(53.9 \%) \\
64(46.1 \%)\end{array}$ & $<0.05$ \\
\hline $\begin{array}{l}\text { Ischemic heart disease } \\
\text { No } \\
\text { Yes }\end{array}$ & $\begin{array}{l}6(75 \%) \\
2(25 \%)\end{array}$ & $\begin{array}{l}5(71.4 \%) \\
2(28.6 \%)\end{array}$ & $\begin{array}{l}8(80 \%) \\
2(20 \%)\end{array}$ & $\begin{array}{l}109(78.4 \%) \\
30(21.6 \%)\end{array}$ & $<0.05$ \\
\hline $\begin{array}{l}\text { Atrial fibrillation } \\
\text { No } \\
\text { Yes }\end{array}$ & $\begin{array}{l}8(100 \%) \\
0(0)\end{array}$ & $\begin{array}{l}7(100 \%) \\
0(0)\end{array}$ & $\begin{array}{l}10(100 \%) \\
0(0)\end{array}$ & $\begin{array}{l}125(89.9 \%) \\
14(10.1 \%)\end{array}$ & $<0.05$ \\
\hline $\begin{array}{l}\text { Previous TIA } \\
\text { No } \\
\text { Yes }\end{array}$ & $\begin{array}{l}7(87.5 \%) \\
1(12.5 \%)\end{array}$ & $\begin{array}{l}6(85.7 \%) \\
1(14.3 \%)\end{array}$ & $\begin{array}{l}5(50 \%) \\
5(50 \%)\end{array}$ & $\begin{array}{l}119(85.6 \%) \\
20(14.4 \%)\end{array}$ & 0.140 \\
\hline $\begin{array}{l}\text { Previous Stroke } \\
\text { No } \\
\text { Yes }\end{array}$ & $\begin{array}{l}2(25 \%) \\
6(75 \%)\end{array}$ & $\begin{array}{l}3(42.9 \%) \\
4(57.1 \%)\end{array}$ & $\begin{array}{l}5(50 \%) \\
5(50 \%)\end{array}$ & $\begin{array}{l}118(84.9 \%) \\
21(15.1 \%)\end{array}$ & $<0.05$ \\
\hline $\begin{array}{l}\text { Family history of stroke } \\
\text { No } \\
\text { Yes }\end{array}$ & $\begin{array}{l}6(75 \%) \\
2(25 \%)\end{array}$ & $\begin{array}{l}7(100 \%) \\
0(0)\end{array}$ & $\begin{array}{l}8(80 \%) \\
2(80 \%)\end{array}$ & $\begin{array}{l}112(80.6 \%) \\
27(19.4 \%)\end{array}$ & $<0.05$ \\
\hline $\begin{array}{l}\text { Antiplatelet use } \\
\text { No } \\
\text { Yes }\end{array}$ & $\begin{array}{l}6(75 \%) \\
2(25 \%)\end{array}$ & $\begin{array}{l}5(71.4 \%) \\
2(28.6 \%)\end{array}$ & $\begin{array}{l}6(60 \%) \\
4(40 \%)\end{array}$ & $\begin{array}{l}111(79.9 \%) \\
28(20.1 \%)\end{array}$ & $<0.05$ \\
\hline $\begin{array}{l}\text { Statin use } \\
\text { No } \\
\text { Yes }\end{array}$ & $\begin{array}{l}6(75 \%) \\
2(25 \%)\end{array}$ & $\begin{array}{l}5(71.4 \%) \\
2(28.6 \%)\end{array}$ & $\begin{array}{l}5(50 \%) \\
5(50 \%)\end{array}$ & $\begin{array}{l}83(59.8 \%) \\
56(40.2 \%)\end{array}$ & $<0.05$ \\
\hline $\begin{array}{l}\text { Presence of carotid bruit } \\
\text { No } \\
\text { Yes }\end{array}$ & $\begin{array}{l}4(50 \%) \\
4(50 \%)\end{array}$ & $\begin{array}{l}5(71.4 \%) \\
2(28.6 \%)\end{array}$ & $\begin{array}{l}6(60 \%) \\
4(40 \%)\end{array}$ & $\begin{array}{l}135(97.1 \%) \\
4(2.9 \%\end{array}$ & $<0.05$ \\
\hline
\end{tabular}

\section{Discussion}

Large vessel atherosclerotic disease is an important etiologic factor for ischemic stroke and TIA. Its timely detection and treatment prevent strokes. Prevalence of extracranial CAS is considered low in Asian population compared to the west. This long held belief may lead to a delay in diagnosis. However extracranial CAS remains an important and treatable cause for ischemic stroke and TIA. Also, timely interventions will reduce recurrent strokes and related morbidity whilst helping to minimize the stroke burden in ant society. According to the AHA/ASA guidelines (2011) on the management of CAS duplex ultrasonography is recommended for asymptomatic as well as symptomatic patients.

Furthermore, MR angiography (MRA) or CT angiography (CTA) should be performed in cases where the duplex scan is inconclusive and where surgical intervention is planned. If the surgical risk is low in patients with over $50 \%$ stenosis causing nondisabling ischemic stroke or TIA, carotid revascularization should be performed soon, preferably within 2 weeks. For patients who have low risk of post intervention complications carotid arterial stenting is recommended as an alternative to CEA. Patient's comorbidities and life expectancy should be taken into consideration if they are asymptomatic. Carotid revascularization is not recommended if the luminal narrowing is less than $50 \%$ or $100 \%$ (complete) and in those with severe disability.

Screening for extracranial CAS is cost effective as devastating recurrent strokes can be prevented. However, CAS screening is inadequate in Sri Lanka like in other Asian countries, especially since it was long assumed to be of a low prevalence compared to the west. It is interesting to note that in this study the prevalence of CAS in acute ischemic stroke in Sri Lanka is 15.2\%, similar to western populations. Advanced age and previous TIAs are significantly associated with CAS. Therefore, it is imperative that all patients with acute ischemic stroke are screened.

The main limitation noted in our study is using only duplex ultrasonography to detect extracranial CAS. Other imaging 
modalities were not included in the protocol. However, compared to 4 vessel digital subtraction angiography (DSA), duplex ultrasonography has an overall sensitivity of $91 \%-95 \%$ and a specificity of $86 \%-97 \%{ }^{[7]}$. Few patients underwent imaging such as CTA and MRA. Our operator bias was minimal as all duplex scans were done by single trained operator and data was collected by a single trained neurology medical officer. This study was carried out in a prospective manner in the largest neurology care center in Sri Lanka on consecutive patients hence can be considered representative.

\section{Conclusion}

The prevalence of extracranial CAS is not rare in Sri Lanka, and is comparable to western figures. Early CAS screening within two weeks should be an integral part of stroke work up.

\section{Ethics approval and consent to Participate}

The ethical approval obtained from the Ethical Review Committee (ERC), National Hospital of Sri Lanka and a copy of approval letter is available for review. The informed written consent obtained from all eligible participants and copies of written consents are available for review.

\section{Declaration of interest}

None; the authors have no competing interests.

\section{Funding}

The authors received no financial support for the research, authorship and publication of this article.

\section{Availability of data and materials}

All data and study materials are available for review.

\section{Author contribution}

All authors were equally contributed, read and approved the final manuscript.

\section{Acknowledgement}

We acknowledge and are indeed grateful to all patients and their families for participation.

\section{References}

[1] Mackay J, Mensah GA. The atlas of heart disease and stroke. World health organization and Center for disease control and prevention. [Last accessed on 2013 Feb 14].

[2] Department of Census and Statistics. Population and Housing Data: Colombo District. Colombo: Ministry of Health; 2011.

[3] Fine-Edelstein JS, Wolf PA, O'Leary DH, et al. Precursors of extracranial carotid atherosclerosisin the Framingham Study. Neurology 1994;44: 1046-50.

[4] Walker MD, Marler JR, Goldstein M, et al. Endarterectomy for asymptomatic carotid artery stenosis.JAMA 1995;273:1421-8.

[5] de Weerd M, Greving JP, Hedblad B, et al.Prediction of asymptomatic carotid artery stenosis in the general population: identification of highrisk groups. Stroke 2014;45: 2366-71.

[6] Jonas DE, Feltner C, Amick HR, et al. Screening for asymptomatic carotid artery stenosis: a systematic review and meta-analysis for the U.S. Preventive Services Task Force. Ann Intern Med 2014;161: 336-46.

[7] Gaitini D, Soudack M. Diagnosing carotid stenosis by Doppler sonography: state of the art. J Ultrasound Med 2005;24:1127-36.

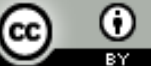

Open Access This article is licensed under a Creative Commons Attribution 4.0 International License, which permits use, sharing, adaptation, distribution and reproduction in any medium or format, as long as you give appropriate credit to the original author(s) and the source, provide a link to the Creative Commons license, and indicate if changes were made. The images or other third party material in this article are included in the article's Creative Commons license, unless indicated otherwise in a credit line to the material. If material is not included in the article's Creative Commons license and your intended use is not permitted by statutory regulation or exceeds the permitted use, you will need to obtain permission directly from the copyright holder. To view a copy of this license, visit https://creativecommons.org/licenses/by/4.0/.

(C) The Author(s) 2021 